\title{
CYTOTOXIC EFFECT FROM ETHYL ACETATE-METHANOL SUBFRACTION OF CARRISA CARANDAS L TOWARD HELA CELLS BY IN VITRO TEST
}

\section{MAMIK P. RAHAYU1 ${ }^{1}$, RESLELY HARJANTI ${ }^{1}$, MAE S. H. WAHYUNINGSIH ${ }^{2}$, SUPARGIYONO ${ }^{2}$}

1Faculty of Pharmacy, Setia Budi University, Central of Java, Indonesia, ${ }^{2}$ Center for Tropical Medicine, Gadjah Mada University, Yogyakarta, Indonesia

Email: pi_er@yahoo.co.id

Received: 05 Feb 2017 Revised and Accepted: 18 Apr 2017

\section{ABSTRACT}

Objective: Cervical cancer is a malignant type of cancer, often affects women, particularly in developing countries. Carrisa carandas leaves contained many secondary metabolites that had potency as an anticancer. The purpose of this study was to understand the cytotoxic effect of a subfraction of Carrisa carandas leaves against HeLa cells.

Methods: Chloroform fraction was separated by VLC gradually with n-hexane-chloroform-ethyl acetate and methanol. The same profiles from eluent chloroform-ethyl acetate composed fraction 18-26 were categorised as Fr4 and ethyl acetate-methanol composed fraction 27-30 as Fr5. The cytotoxic effect was evaluated by MTT assay on HeLa cells

Results: The result showed that the cytotoxic effect of subfraction Fr4 and Fr5 had IC 50 values of $177 \mathrm{mg} / \mathrm{ml}$ and $98 \mathrm{mg} / \mathrm{ml}$, respectively. Colourless crystal of Subfraction Fr 5-3 had IC 50 value of $333 \mathrm{mg} / \mathrm{ml}$. Subfraction Fr 5 showed effective cytotoxic activity than the others. Conclusion: It had chemo-preventive effect against cancer cells

Conclusion: This study applied MTT (Microculture Tetrazolium) method by in vitro test. The advantages of this method are relatively rapid, sensitive and accurate

Keywords: Carandas leaves (Carissa carandas L), Cytotoxic, MTT assay,sub Fraction

(C) 2017 The Authors. Published by Innovare Academic Sciences Pvt Ltd. This is an open access article under the CC BY license (http://creativecommons.org/licenses/by/4.0/) DOI: http://dx.doi.org/10.22159/ajpcr.2017v10s3.21355

\section{INTRODUCTION}

Cancer is being the main health problem in the world and the biggest killer disease after cardiovascular. One of the most often cancers found in women is cervical cancer. It is the malignant type of cancer especially in developing countries [1]. The number of the sufferer is around 40 people per 100 thousand. In Indonesia, it is approximately between 25 and 40 in every 100 thousand people per year [2]. Carissa has been widely used for traditional medicine specifically as an anticancer. Carissa carandas is shrub plant of family Apocynaceae. Chemical compounds in this plant were alkaloids, anthraquinone, terpenoids, and flavonoid. Non polar compound found in leaves were triterpene carandinol, betulinic acid, $\beta$-cytosterol-3-0- $\beta$-d-glucopyranoside, ursolic acid, ursuline acid, and hydroxybenzoate acid [3]. Activities of Carissa fraction reported are antipyretic, anthelmintic, antitumor, insecticide, antioxidant, and antimicrobial [4]. Other reports, water extract of Carissa's leaves had activities as antioxidant and anticancer [5] while chloroform extract had activities as anti-cancer for Hela cell in ovarium with $\mathrm{EC}_{50}$ of $7.702 \mu \mathrm{g} / \mathrm{m}$ [6]. This study aimed to determine the cytotoxic activity of subfraction of Carrisa carandas leaves against HeLa cells by in vitro test with MTT method (Microculture Tetrazolium Salt) which was indicated by the $\mathrm{IC}_{50}$ value.

\section{MATERIALS AND METHODS}

\section{Materials}

All chemical reagents and solvents were purchased from Bratachem and Sigma Aldrich. Carissa carandas was obtained from Solo, Central Java, particularly leaves of Carissa as the main material. The research was conducted at Pharmaceutical Biology Laboratorium of Universitas Sebelas Maret.

\section{Procedure of fractionation}

Methanolic extracts were prepared by maceration carried out for seven days with methanol. Obtained extract was then partitioned with $75 \mathrm{ml}$ of distilled water and $75 \mathrm{ml}$ chloroform (1: 1) three times. The chloroform phase was separated using vacuum coloumn chromatography. Silica gel 60 was used for the stationary phase. Thirty fractions were gained from the separation. Fractions that had the same amount of chromatogram and Rf value were compiled and was acquired 5 compiled fractions. The same profiles from chloroform-ethyl acetate eluent were composed as fraction 18-26 and were categorized as Fr4. Besides, ethyl acetate-methanol eluent was composed as fraction 27-30 and was categorized as Fr5.

\section{Cytotoxic activity test}

Approximately $10 \mathrm{mg}$ of sample was diluted into $50 \mathrm{ml}$ of DMSO (dimethyl sulfoxide) in Eppendorf as test agent and stock solution. To make series of solutions for the treatment levels was conducted aseptically in the LAF (Laminar Air Flow) cabinet. Each of stock solutions was taken $10 \mu \mathrm{l}$ then added into $90 \mu \mathrm{l}$ of culture medium. Afterwards, it was made for some various concentrations for each test. Each subsequent concentration was taken about $100 \mu \mathrm{l}$ into each of hole/well with three times repetition for each concentration.

\section{Cytotoxic MTT test (Microculture tetrazolium salt)}

HeLa cells were suspended at a density of $3 \times 104$ cells/hole. About $100 \mu \mathrm{l}$ of the cell was inserted in microplate 96 holes and incubated in $5 \%$ of $\mathrm{CO}_{2}$ condition at $37{ }^{\circ} \mathrm{C}$ for $24 \mathrm{~h}$. The holes contained cell suspension was added into $100 \mu \mathrm{l}$ of test solution in each hole in order to obtain particular various concentration $(100 ; 50 ; 25 ; 12.5$; 6.25) $\mu \mathrm{g} / \mathrm{ml}$ per hole. Control medium was the cell without an additional solution. At the end of incubation process, the medium was removed and washed using FBS (Fetal Bovine Serum) then was added by $100 \mu \mathrm{l}$ of new media and $10 \mu \mathrm{l}$ MTT $5 \mathrm{mg} / \mathrm{ml}$ in FBS. Microplates were incubated again for $4 \mathrm{~h}$ at $5 \% \mathrm{CO}_{2}$ at $37{ }^{\circ} \mathrm{C}$. Living cell would react with MTT to form purple formazan. To stop the 
reaction between cells and MTT and to dissolve formazan, it was added by $100 \mathrm{ml}$ of SDS (Sodium Dodecyl Sulphate) $10 \%$ in $0.01 \mathrm{~N}$ $\mathrm{HCl}$, incubated for $24 \mathrm{~h}$ at room temperature. Finally, absorbance was observed using ELISA reader at $595 \mathrm{~nm}$.

\section{Analysis}

The percentage of living cell was determined by this equation: $\mathrm{IC}_{50}$ is value that induces $50 \%$ live Hela cell and is measured by linier regression with probity percentage as ordinat and log value as absis [7]

$$
=\frac{\text { treated absorbance }- \text { control media absorbance }}{\text { control absorbance }- \text { control media absorbance }} \times 100 \%
$$

\section{RESULTS}

Cytotoxic test of Fr4 and Fr6 from Carissa's leaves toward Hela cells culture can be seen by morphological observation of cells themselves [8] The differences between living cells and dead cells will be clearly visible after exposuring MTT salt. This was caused the living cells can reduce MTT to become formazan purplish crystal. Living cells morphology was round, clear and vivid slightly. The dead cells would be muddy because they were lost of cytoplasm as a consequent of broken cells membrane. This presented that subfraction of Carissa's leaves could inhibit Hela cells proliferation

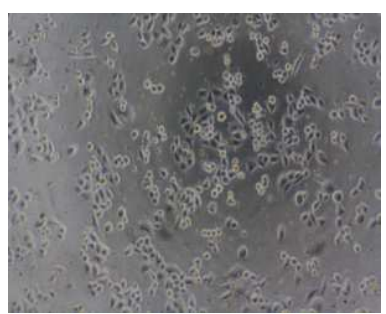

A

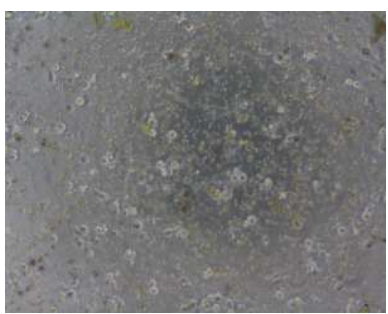

Fig. 1: The morphology of Hela cells of Fr5 $(500 \mu \mathrm{g} / \mathrm{ml})$ from Carissa's leaves a) before MTT administering; b) after administering

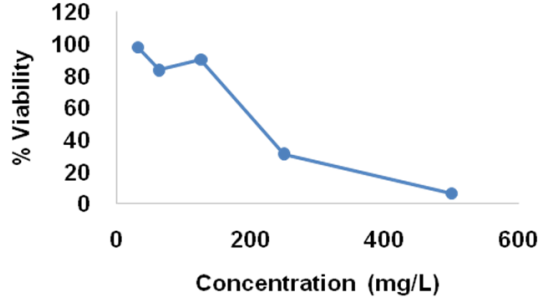

Fig. 2: Cytotoxic activity of subfraction from Fr 4 of leaves Carissa carandas in HeLa cell lines

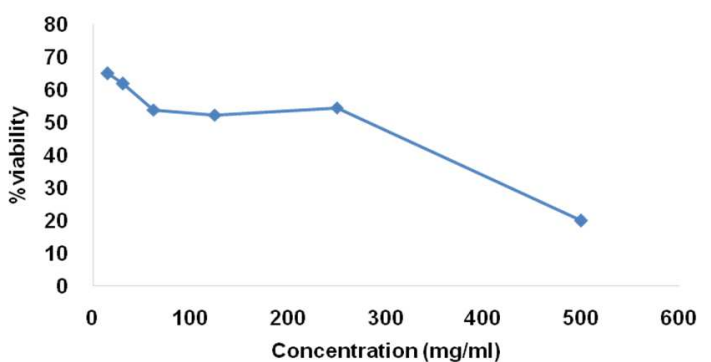

Fig. 3: Cytotoxic activity of subfraction Fr 5 of leaves $C$. carandas in HeLa cell lines

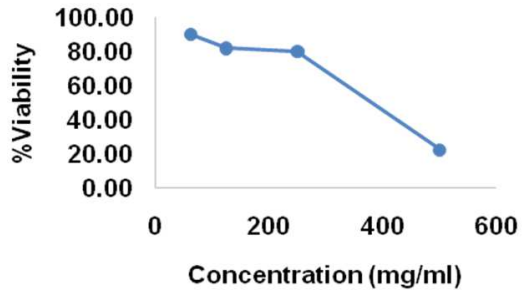

Fig. 4: Cytotoxic activity of subfraction from Fr 5-3 of leaves $C$ carandas in HeLa cell lines

Table 1: IC50 value of sub fraction from Fr 4, Fr 5 and Fr 5-3 of C. carandas in HeLa cell lines

\begin{tabular}{lll}
\hline Subfraction & Linear regression & IC $_{\mathbf{5 0}}$ \\
\hline Fr 4 & $\mathrm{y}=-23.476 \mathrm{x}+96.881$ & 177 \\
Fr 5 & $\mathrm{y}=-77.832 \mathrm{x}+225.07$ & 98 \\
Fr 5-3 & $\mathrm{y}=-68.054 \mathrm{x}+221.7$ & 333 \\
FR 5-4 & $\mathrm{y}=-10.814 \mathrm{x}+105.02$ & $>333$ \\
\hline
\end{tabular}

\section{Identification and spectra analysis of subfraction Fr5-3 and Fr5-4}

Fr5-3 was the unpured compound resulted from recrystallization process using chloroform of subfraction 5. Identification using KLT with a mobile phase of chloroform: methanol (9:0.5) with Liebermann Burchard showed dark purplish in RF 0.7. According to FTIR spectra, the compound consisted of the hydroxyl group at $3728 \mathrm{~cm}^{-1}$, methylene group at $823 \mathrm{~cm}^{-1}$ and carbonyl group at $1017 \mathrm{~cm}^{-1}$. Strong intensity peak at less $1000 \mathrm{~cm}^{-1}$ was probably bonding between carbon and halogen element. Fr5-4 was white crystal. According to FTIR spectra of Fr5-4, their C-O carbonyl presents at $1650 \mathrm{~cm}^{-1}$ and also stretching $\mathrm{OH}$ from alcohol group at $3450 \mathrm{~cm}^{-1}$, separately with $\mathrm{CH}(\mathrm{sp} 3)$ at $2960 \mathrm{~cm}^{-1}$. Alcohol group is supported by carbonyl group at $1100 \mathrm{~cm}^{-1}$. Another sharp peak presents at $2500-2000 \mathrm{~cm}^{-1}$ that indicates $\mathrm{CN}$ group amplified with twin peaks at $3700 \mathrm{~cm}^{-1}$

Obtained compound was analysis using LC-MS Spectrophotometer via ESI (Electron Spray Ionization). The chromatogram shows a single peak at time retention of $2.67 \mathrm{~min}$ that indicated the main compound. Other peaks that appeared were pointed out the contaminants. Continued with MS spectrophotometer, MS spectra showed base peak $\mathrm{m} / \mathrm{z}$ with value of 361.19 . It was the most stable ion that indicated the weight molecule. The fragmentation patterns were still complicated because there were only methyl, ethyl, and hydroxyls group that released as the fragments.

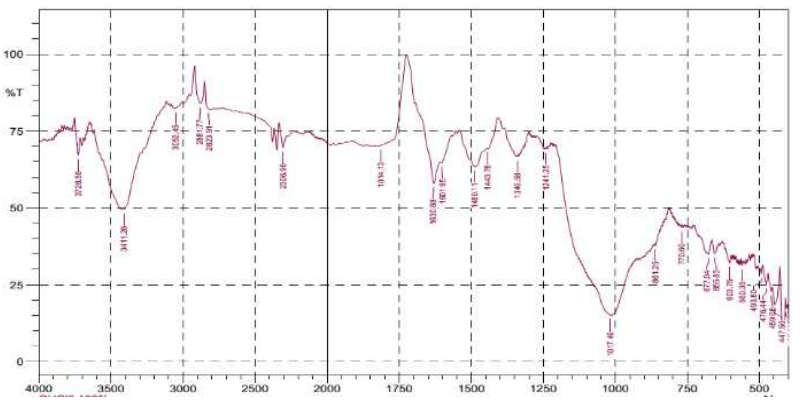

Fig. 5: IR spectrum of subfraction Fr5-3 


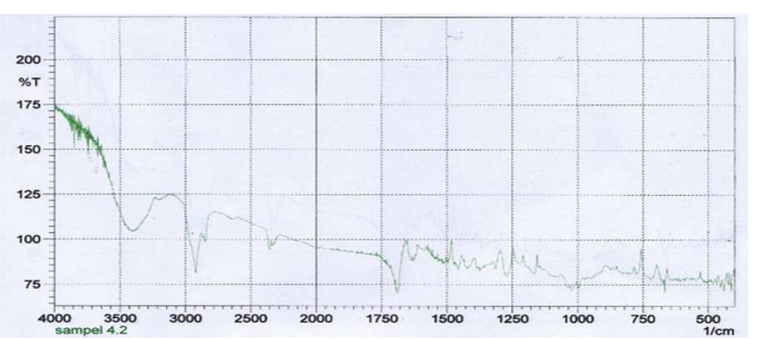

Fig. 6: IR spectrum of subfraction Fr5-4

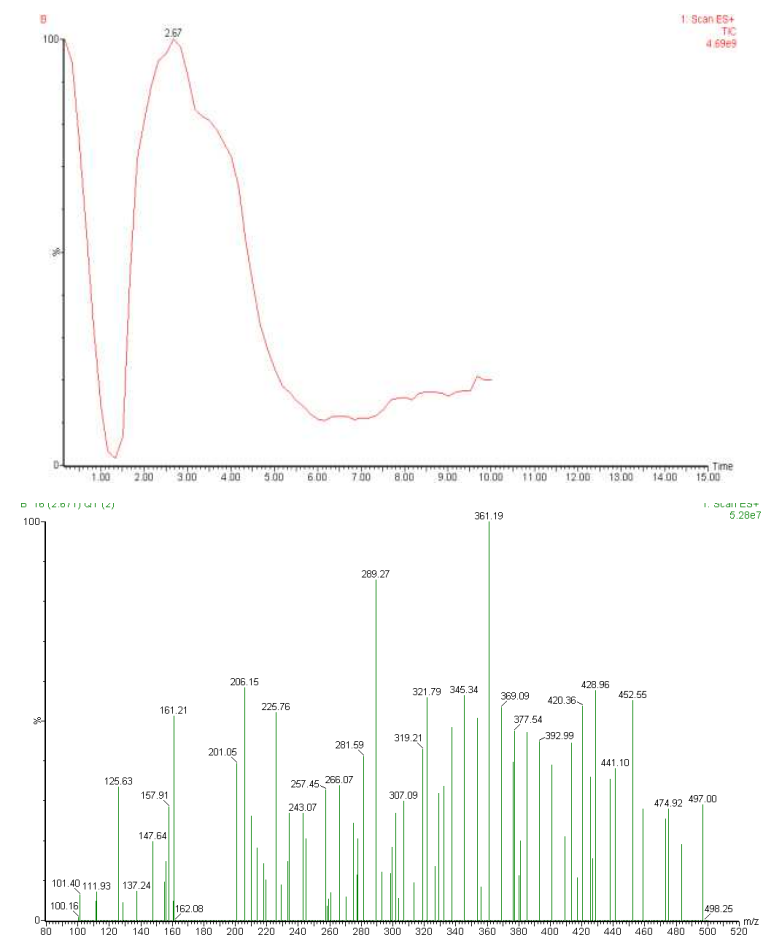

Fig. 7: Chromatogram and mass spectrum of subfraction Fr5-4

\section{DISCUSSION}

This study applied MTT (Microculture Tetrazolium) method by in vitro test. The advantages of this method are relatively rapid, sensitive and accurate [9]. MTT is a colorimetric method which MTT reagent (Tetrazolium 3-(4,5-Dimethylthiazol2-yl)-2,5 Diphenyltetrazolium Bromide salt) can be disparted into formazan salt by succinate tetrazolium in respiration track of cell (in mitochondria) in any living cell. Formazan salt is soluble salt at SDS (Sodium Dodecyl Sulphate) $10 \%$ in $0,1 \mathrm{~N} \mathrm{HCl}$ but not soluble in water. It is a purple salt [10]. Viability cells method is one of anticancer activity test methods regarding to the ability of cells to survive after administering toxic compound. Calculation of viability percentage can find the number of living cells after administering. From the calculation, it can be seen about reducing of viability percentage from the lower concentration to higher concentration. The higher concentration of the sample, the lower viability percentage obtained. IC50 for the cytotoxic test can be called as very active if the value is $<10 \mu \mathrm{g} / \mathrm{ml}$, active if the value between 10 and $20 \mu \mathrm{g} / \mathrm{ml}$ and less active if more than $20 \mu \mathrm{g} / \mathrm{ml}$. But if the value of IC50 is $<100 \mu \mathrm{g} / \mathrm{ml}$, it can still be called as a chemopreventive agent against cancer cells[11]. Chemopreventive is retardment of cancer cells growth which the retarder is given at before or simultaneously with induction agent. Chemopreventice can use natural pharmacological agents that typically inhibit cancer cells growth. The agents have to comply standard of the security levels and efficacy for therapeutic [12]. Based on The American National Cancer Institute, an extract that can be called having cytotoxic activity if the value of IC50 is $<20 \mu \mathrm{g} / \mathrm{ml}[13]$.
IC50 value of Fr5 is bigger than Fr4. Carrisa carandas contained carandinol that had cytotoxic activity toward Hela cells [6]. The result of phytochemical screening of $\mathrm{Fr} 4$ was not found out any terpenoid compound. Triterpene can induce calcium $\left(\mathrm{Ca}^{2+}\right)$ which can stimulate cell death in tumor cells or cancer by blocking the cell cycle at the G2/M phase with stabilizing threads Spindle in the phase of mitosis so that the process of mitosis can be inhibited [14]. One class of flavonoids that alleged role in the cytotoxic effect was flavon or flavonol which can induce discontinuation phase G1 by damaging the DNA of cells [15]. The alkaloids can inhibit the enzyme activity of DNA topoisomerase II; an enzyme that plays an important role in the process of replication transcription, DNA recombination, and the proliferation of cancer cells that causes death by apoptosis [16].

\section{CONCLUSION}

Subfraction Fr 4 and 5 showed effective cytotoxic activities. Carissa carandas leaves had a cytotoxic effect on HeLa cells with $\mathrm{IC}_{50}$ values of $98 \mathrm{mg} / \mathrm{ml}$ and $177 \mathrm{mg} / \mathrm{ml}$, respectively. Fr 5-3 and Fr5-4 subfraction did not have cytotoxic effect on HeLa cells with $\mathrm{IC}_{50}$ value of $333 \mathrm{mg} / \mathrm{ml}$ and $>333 \mathrm{mg} / \mathrm{ml}$.

\section{CONFLICTS OF INTERESTS}

\section{Declared none}

\section{REFERENCES}

1. Cronje HS. Screening of cervical cancer in developing countries. Int J Gynecol Obstery 2004;84:101-8.

2. de Boer M, AW Peter L, Aziz MF, Siregar B, Cornain S, Vrede MA, et al. Human papillomavirus type 16 E6, E7 and L1 variant in cervical cancer in Indonesia, Suriname, Netherland. Gynecol Oncol 2004;94:488-94.

3. Fatima A, Singh PP, Agarwal P, Irchhail R, Alok S, Amita V. Treatment of various disease by carissa spinarum L.-A Promising Scrubs; 2013.

4. Bhaskar VH, Balakrishan N. Analgesic, anti-inflamatory and antipiretic of Pergularia danemia and Carissa carandas. DARU 2009;17:168-74.

5. Dua D, Srivastav SN. Cancerous and antioxidant potential of aqueous extracts of annona reticulata, podophyllum peltatum, psidium guajava, ananas comosus, carissa carandas on Mcf 7 cancer cell line. Int J Integr Sci Innovation Technol 2013;2:15-9.

6. Sabira Begum, Saqib A Syed, Bina S Siddiqui, Samina A Sattar, M Iqbal Choudhary. First isohopane triterpene from the leaves of Carissa carandas L and its cytotoxicity against cancer cell lines. Phytochemycal Lett 2013;91-5. Doi:10.1016/j.phytol. 2012.11.005.

7. Ueda JY, Tesuka Y, Banskota AH, Tran QL, Hariyama Y, Saiki I, et al. Antiprolifrative activity of vietnamese medicinal plants. Biol Pharm Bull 2002;25:753-60.

8. Doyle, A dan Griffithf JB. Cell and Tissue Culture For Medical Research. New York. John Wiley and Sond Ltd; 2000.

9. Freshney RI. Culture of Animal Cells. A Manual of Basic Technique. $5^{\text {th }}$ edition. New York; 2000.

10. CCRC. Farmasi. Sel HeLa. UGM yogyakarta; 2009. Available from: http://www.CCRC.Farmasi.UGM.ac.id. [Last accessed on 01 Jul 2004].

11. Gritter R, Bobbit J, Schwarting A. Introduction to chromatography, translated by Padmawinata K. Bandung: ITB; 1985.

12. Kakizoe T. Chemoprevention of cancer focusing on cinical trial, Nationa Cancer Center. Jpn J Clin Oncol 2003;33:421-42.

13. Lee CC, Houghton P. Cytotoxicity of plants from Malaysia and Thailand used traditionally to treat cancer. J Ethnopharmacol 2005;100:237-43.

14. Ren W, Qiao Z, Wang H, Zhu L, Zhang L. Flavonoids: promising anticancer agents. Med Res Rev 2003;23:519-34.

15. Pan MH, Chen WJ, Lin S, Ho CH, Lin JK. Tangeretin induces cell cycle through inhibiting cyclin dependent kinase 2 and 4 activities as well as elevating cdk inhibitor p21 in human colorectal carcinoma cells. Carcinogenesis 2002;23:1677-84.

16. Cotran RS, Kumar V, Collin T. Neoplasia in robbins pathologic basic of disease. Sixth Edition. Philadelphia: WB Saunders Company; 1999. p. 260-325. 